\title{
ANALISIS KETERPADUAN MODA TRANSPORTASI ANGKUTAN PENYEBERANGAN DENGAN JALAN RAYA DI PELABUHAN BAJOE KAB. BONE
}

\author{
Windra Priatna Humang ${ }^{1}$, A. Zulfadly ${ }^{2}$ \\ ${ }^{1}$ Dosen FT Universitas Andi Djemma Palopo \\ ${ }^{2}$ Pegawai Dinas PU Kabupaten Bone \\ 1indrahumang@gmail.com, ${ }^{2}$ zulfadlisaja@yahoo.com
}

\begin{abstract}
Abstrak
Penelitian ini bertujuan (1) menggambarkan kondisi operasional moda transportasi angkutan penyeberangan dan jalan raya dalam melayani penumpang dan kendaraan bermotor di Pelabuhan Bajoe Kabupaten Bone, (2) Merumuskan prioritas pengembangan keterpaduan moda transportasi angkutan penyeberangan dengan jalan raya.Penelitian dilaksanakan di Kabupaten Bone Provinsi Sulawesi Selatan. Pengumpulan data dilakukan melalui survei lapangan dan kuisioner. Hasil penelitian menunjukkan bahwa armada kapal fery yang beroperasi di Pelabuhan Bajoe sebanyak 9 buah belum mampu melayani besarnya permintaan muatan khususnya muatan kendaraan truk barang. Sedangkan akses jalan Makassar-Bone yang merupakan jalur utama muatan di Pelabuhan Bajoe memiliki tingkat pelayanan A dengan derajat kejenuhan 0,17. Hasil analisis terhadap urutan prioritas pengembangan keterpaduan transportasi penyeberangan dengan angkutan jalan raya di pelabuhan Bajoe berturut-turut adalah penambahan kapasitas/jumlah armada kapal feri, peningkatan/pelebaran akses jalan Makassar-Bone, penyediaan angkutan penumpang khusus Makassar-Bajoe dan perbaikan jalan trans Sulsel-Sultra.
\end{abstract}

Kata kunci : Keterpaduan, Moda Transportasi, Angkutan Penyeberangan, Angkutan Jalan

\section{PENDAHULUAN}

Sistem jaringan transportasi dapat dilihat dari segi efektivitas, dalam arti selamat, aksesibilitas tinggi, terpadu, kapasitas mencukupi, teratur, lancar dan cepat, mudah dicapai, tepat waktu, nyaman, tarif terjangkau, tertib, aman, rendah polusi serta dari segi efisiensi dalam arti beban publik rendah dan utilitas tinggi dalam satu kesatuan jaringan sistem transportasi. Oleh karena itu, pengembangan transportasi sangat penting artinya dalam menunjang dan menggerakkan dinamika pembangunan, karena transportasi berfungsi sebagai katalisator dalam mendukung pertumbuhan ekonomi dan pengembangan wilayah. Jika dilihat dari aspek kepentingan publik, sistem transportasi yang meliputi transportasi darat, laut dan udara mengemban fungsi pelayanan publik dalam skala domestik maupun internasional. Pengembangan transportasi harus didasarkan pada pengembangan yang berkelanjutan (sustainability). Perencanaan jangka pendek harus didasarkan pada pandangan jangka panjang, sehingga tidak terjadi perencanaan "bongkar-pasang".

Keberhasilan pembangunan sangat ditentukan oleh peran sektor transportasi. Karenanya sistem transportasi harus dibina agar mampu menghasilkan jasa transportasi yang handal, berkemampuan tinggi dan diselenggarakan secara terpadu, tertib, lancar, aman, nyaman dan efisien dalam menunjang dan sekaligus menggerakkan dinamika pembangunan; mendukung mobilitas manusia, barang serta jasa; mendukung pola distribusi nasional serta mendukung pengembangan wilayah dan peningkatan hubungan internasional yang lebih memantapkan perkembangan kehidupan berbangsa dan bernegara dalam rangka perwujudan Wawasan Nusantara. Dalam pembangunan transportasi, Pemerintah Pusat, Pemerintah provinsi maupun Pemerintah Kabupaten/Kota mempunyai peranan sesuai cakupan kewenangannya masing-masing, yaitu kewajiban untuk menyusun rencana dan merumuskan 
kebijakan, mengendalikan dan mengawasi perwujudan transportasi. Salah satu kewajiban yang dimaksud adalah menetapkan jaringan sarana transportasi dan jaringan pelayanan. Termasuk juga kewajiban untuk melaksanakan tugas pembangunan sarana dan prasarana transportasi dengan prioritas daerah-daerah yang kurang berkembang.

Kota Watampone sebagai ibukota Kabupaten Bone merupakan salah satu kota di Provinsi Sulawesi Selatan yang mengalami perkembangan yang signifikan, baik perkembangan ekonominya maupun pertambahan jumlah penduduk. Sehingga kebutuhan masyarakat akan pelayanan transportasi semakin meningkat akibat peningkatan mobilitas manusia dan barang. Sistem transportasi yang diselenggarakan di Kota Watampone terdiri atas moda transportasi darat dan penyeberangan laut di pelabuhan Bajoe yang menghubungkan Kabupaten Bone dengan Kabupaten Kolaka Provinsi Sulawesi Tenggara. Penyeberangan ini dilayani dengan menggunakan kapal feri yang mengangkut penumpang barang dan orang serta kendaraan bermotor seperti Truk, Bus dan minibus dari beberapa Kabupaten/Kota di Sulawesi Selatan, Sulawesi Barat dan Sulawesi Tengah menuju ke Kabupaten Kolaka Provinsi Sulawesi Tenggara.

Sasaran transportasi nasional adalah untuk terciptanya pelayanan transportasi yang efektif dan efisien. Efektif dalam arti aksesibilitas tinggi, kapasitas mencukupi, tarif terjangkau, tertib, teratur, lancar dan cepat, aman, mudah, tepat waktu, nyaman serta efisien dalam satu kesatuan jaringan transportasi. Hirarki Jaringan transportasi terdiri dari jaringan pelayanan dan jaringan prasarana, meliputi: (1) jaringan prasarana transportasi jalan terdiri dari simpul yang berwujud terminal penumpang dan terminal barang dan ruang lalu lintas. Jaringan jalan terdiri atas jaringan jalan primer dan jaringan jalan sekunder; (2) jaringan Pelayanan angkutan orang dengan kendaraan umum dikelompokkan menurut wilayah pelayanan, operasi pelayanan dan perannya. Menurut sifat pelayanannya, angkutan penumpang dengan kendaraan umum dapat dilaksanakan dalam trayek dan tidak dalam trayek.

Peran transportasi dalam Propenas (2000) yaitu sebagai pendukung kegiatan ekonomi dan berfungsi untuk menyediakan jasa pelayanan bagi arus pergerakan orang dan brang khususnya dalam distribusi barang dan jasa dari sumber bahan baku ke tempat produksi serta lokasi pemasarannya baik di tingkat lokal, regional, nasional maupun internasional. Sementara peran transportasi menurut RPJMN (2004) adalah sebagai katalisator mendukung pertumbuhan ekonomi, pengembangan wilayah dan pemersatu Negara Kesatuan Republik Indonesia.

Angkutan penyeberangan adalah angkutan yang berfungsi sebagai jembatan yang menghubungkan jaringan jalan dan/atau jaringan jalur kereta api yang dipisahkan oleh perairan untuk mengangkut penumpang dan kendaraan beserta muatannya. Menurut Hany dan Ahmed Assqol (2009), Pelabuhan penyeberangan masuk dalam jenis pelabuhan khusus yang dipergunakan untuk angkutan penyeberangan dengan menggunakan kapal Ro-Ro. Dalam bongkar muat kapal jenis ini membutuhkan sebuah dermaga, biasanya dilengkapi dengan jembatan apung (movable bridge) pada ujung dermaga untuk mengantisipasi pasang surut air laut. Fasilitas pokok pelabuhan penyeberangan terdiri atas dermaga dan parkir kendaraan (tunggu) yang akan berangkat.

Dalam Undang-undang No. 38 tahun 2004, jalan didefinisikan sebagai prasarana transportasi darat yang meliputi segala bagian jalan, termasuk bangunan pelengkapnya yang diperuntukkan bagi lalu lintas, yang berada pada permukaan 
tanah, diatas permukaan tanah, di bawah permukaan tanah/air, serta diatas permukaan air, kecuali kereta api dan jalan kabel, juga disebutkan bahwa sistem jaringan jalan adalah satu kesatuan ruas jalan yang saling menghubungkan dan mengikat pusat-pusat pertumbuhan dengan wilayah yang berada dalam pengaruh pelayanannya dalam satu hubungan hirarkis.

Tingkat pelayanan suatu jalan telah pula didefinisikan menjadi dua kondisi; pertama, tingkat pelayanan tergantung pada rasio antara volume dengan kapasitas; kedua, yaitu tingkat palayanan tergantung fasilitas dimana hal ini sangat tergantung dari jenis fasilitas pada ruas jalanan (Tamin O.Z, 2000). Untuk menentukan batas tingkat pelayanan kapasitas jalan dapat dijelaskan pada tabel 1 berikut :

Tabel 1. Karakteristik tingkat pelayanan dan indeks tingkat pelayanan (ITP)

\begin{tabular}{|c|c|c|c|}
\hline $\begin{array}{l}\text { Tingkat } \\
\text { Pelayanan }\end{array}$ & Karakteristik-karakteristik & $\begin{array}{l}\text { Kecepatan rata- } \\
\text { rata }(\mathrm{Km} / \mathrm{jam})\end{array}$ & $\begin{array}{l}\text { Derajat } \\
\text { Kejenuhan }\end{array}$ \\
\hline A & $\begin{array}{l}\text { Arus lalulintas bebas antara satu kendaraan } \\
\text { dengan kendaraan lainnya, besarnya kecepatan } \\
\text { sepenuhnya ditentukan oleh keinginan pengemudi } \\
\text { dan sesuai dengan batas kecepatan yang telah } \\
\text { ditentukan. }\end{array}$ & $\geq 90$ & $\leq 0.35$ \\
\hline $\mathrm{B}$ & $\begin{array}{l}\text { Kondisi arus lalulintas stabil, kecepatan operasi } \\
\text { mulai dibatasi oleh kendaraan lainnya dan mulai } \\
\text { dirasakan hambatan oleh kendaraan di sekitarnya. }\end{array}$ & $\geq 70$ & $\leq 0.54$ \\
\hline $\mathrm{C}$ & $\begin{array}{l}\text { arus lalulintas masih dalam batas stabil, kecepatan } \\
\text { operasi mulai dibatasi dan hambatan dari } \\
\text { kendaraan lain semakin besar. }\end{array}$ & $\geq 50$ & $\leq 0.77$ \\
\hline $\mathrm{D}$ & $\begin{array}{l}\text { Arus lalulintas mendekati tidak stabil, kecepatan } \\
\text { operasi menurun relatif cepat akibat hambatan } \\
\text { yang timbul, dan kebebasan bergerak relatif kecil. }\end{array}$ & $\geq 40$ & $\leq 0.93$ \\
\hline $\mathrm{E}$ & $\begin{array}{l}\text { Volume lalulintas sudah mendekati kapasitas ruas } \\
\text { jalan, kecepatan kira-kira lebih rendah dari } 40 \\
\text { km/jam. Pergerakan lalulintas kadang terhambat. }\end{array}$ & $\geq 33$ & $\leq 1.0$ \\
\hline $\mathrm{F}$ & $\begin{array}{l}\text { Arus lalulintas berada dalam keadaan dipaksakan, } \\
\text { kecepatan relatif rendah, arus lalulintas sering } \\
\text { terhenti sehingga menimbulkan antrian kendaraan } \\
\text { yang panjang. }\end{array}$ & $<33$ & $>1.0$ \\
\hline
\end{tabular}

Pengukuran tingkat pelayanan jalan dapat diketahui dengan melihat variablevariabel antara lain kapasitas (C), derajat kejenuhan (DS), kecepatan (V), dan waktu tempuh (T). Derajat kejenuhan (DS) dapat dihitung dengan menggunakan perbandingan arus lalu lintas dengan kapasitas ruas jalan, dan digunakan untuk analisa perilaku lalu-lintas berupa kecepatan yang dinyatakan dalam satuan mobil penumpang (smp/jam) dengan persamaan sebagai berikut : ( MKJI;1997)

Dimana :

$$
\mathrm{DS}=\mathrm{Q} / \mathrm{C}
$$

$\mathrm{Q}=$ = Volume atau arus lalu lintas ( $\mathrm{smp} / \mathrm{jam})$

$\mathrm{C} \quad=$ Kapasitas ( $\mathrm{smp} / \mathrm{jam})$

DS $\quad=$ Derajat kejenuhan

Sedangkan kapasitas adalah arus maksimum melalui suatu titik di jalan yang dapat dipertahankan persatuan jam pada kondisi tertentu. Untuk jalan dua lajur dua arah, kapasitas ditentukan untuk arus dua arah (kombinasi dua arah), tetapi untuk jalan dengan banyak lajur, arus dipisahkan perarah dan kapasitas ditentukan perlajur. Kapasitas dinyatakan dalam satuan mobil penumpang (SMP) 
Persamaan umum untuk menghitung kapasitas suatu ruas jalan menggunakan persamaan dari Manual Kapasitas Jalan Indonesia (MKJI, 1997;6-18) untuk jalan luar kota sebagai berikut:

dimana:

$$
\mathrm{C}=\mathrm{CO} \times \mathrm{FCW} \times \text { FCSP } \mathrm{x} \quad \text { FCSF }
$$

$\mathrm{C} \quad=$ Kapasitas $(\mathrm{smp} / \mathrm{jam})$

$\mathrm{CO}=$ Kapasitas dasar ( $\mathrm{smp} / \mathrm{jam})$

FCW = Faktor penyesuaian lebar jalur lalu-lintas

FCSP $=$ Faktor penyesuaian pemisahan arah

FCSF $=$ Faktor penyesuaian hambatan samping

Kinerja operasional pelayanan tranportasi harus dilakukan melalui pendekatan keterpaduan antar moda. Kata "terpadu" (Jinca, 2006) mempunyai arti bahwa kegiatan transportasi dilakukan secara menyeluruh, yang meliputi seluruh sub sektor (darat, penyeberangan, laut dan udara) dan menyatu membentuk suatu kesatuan sistem yang terpadu. Kinerja tingkat pelayanan transportasi yang efisien dan efektif dapat diketahui dari kinerja pelayanan seluruh moda transportasi. Keterpaduan antar moda dapat berupa keterpaduan fisik, yaitu titik simpul pertemuan antar moda terletak dalam satu bangunan, misalnya bandara, terminal bus dan stasiun kereta api merupakan satu bangunan atau terletak berdekatan atau keterpaduan sistem, yaitu titik simpul dari masing-masing moda tidak perlu pada satu bangunan, tetapi ada suatu sitem jaringan transportasi yang menghubungkan titik simpul antar moda, sehingga merupakan satu kesatuan yang utuh. Keterpaduan secara sistem juga menyangkut jadual keberangkatan, pelayanan pembelian karcis serta pengelolaannya. Dengan keterpaduan tersebut, akan memudahkan perjalanan, walaupun harus berganti moda sampai beberapa kali. Keterpaduan antar moda juga akan meningkatkan penggunaan angkutan umum.

\section{METODOLOGI PENELITIAN}

Jenis penelitian yang digunakan bersifat deskriptif dengan pendekatan kualitatif yang bertujuan menggambarkan secara sistematis, cermat dan akurat mengenai keterpaduan moda transportasi angkutan penyeberangan dengan angkutan jalan raya sebagai faktor penting dalam peningkatan ekonomi wilayah. Pengumpulan data dilakukan melalui survey lapangan dan kuisioner kepada stakeholders yang merupakan pihak berkompeten dalam pengembangan transportasi. Analisis tingkat pelayanan jalan menggunakan metode manual kapasitas jalan Indonesia (MKJ) dan analisis prioritas pengembangan keterpaduan angkutan penyeberangan dengan jalan raya menggunakan analysis hierarchy process (AHP).

\section{HASIL DAN PEMBAHASAN}

Kabupaten Bone merupakan salah satu kabupaten di pesisir timur Provinsi Sulawesi Selatan yang berjarak $174 \mathrm{~km}$ dari Kota Makassar dan memiliki garis pantai sepanjang $138 \mathrm{~km}$ dari arah selatan ke utara. Luas wilayah Kabupaten Bone adalah $4.559 \mathrm{~km}^{2}$, dengan batas wilayah sebagai berikut: (1) sebelah Utara berbatasan dengan Kabupaten Wajo dan Soppeng; (2) sebelah Timur berbatasan dengan Teluk Bone; (3) sebelah Selatan berbatasan dengan Kabupaten Sinjai dan Gowa; (4) sebelah Barat berbatasan dengan Kabupaten Maros, Pangkep dan Barru. Jumlah penduduk Kabupaten Bone berdasarkan data BPS dan Bappeda Kabupaten Bone tahun 2009 mencapai 711.748 jiwa, tersebar di 27 kecamatan dengan 
konsentrasi penduduk terbesar di Kecamatan Tanete Riattang, Tanete Riattang Barat dan Tanete Riattang Timur. Ketiga kecamatan tersebut dulunya merupakan wilayah Kota Administratif (Kotif) Watampone.

Kota Watampone merupakan ibukota Kabupaten Bone yang dalam konteks regional wilayah Propinsi Sulawesi Selatan berada pada posisi strategis berdasarkan kedudukan wilayah sebagai pusat pelayanan wilayah Timur. Pengembangan Kota watampone kedepan diarahkan untuk mengemban fungsi pusat pengembanagan antar wilayah (PPAW), pusat pelayanan kabupaten Bone secara keseluruhan dan pusat pelayanan lokal (internal). Wilayah perkotaan Watampone terdiri dari tiga wilayah kecamatan yaitu: Kecamatan Tanete Riattang Barat, Kecamatan Tanete Riattang, dan Kecamatan Tanete Riattang Timur yang mencakup wilayah seluas 126,35 km2. Pelabuhan Bajoe secara administratif berada di Kecamatan Tanete Riattang Timur yang terletak di pesisir pantai timur provinsi Sulawesi Selatan dengan batas timurnya adalah Teluk Bone yang menghadap ke pesisir pantai barat Kabupaten Kolaka Sulawesi Tenggara.

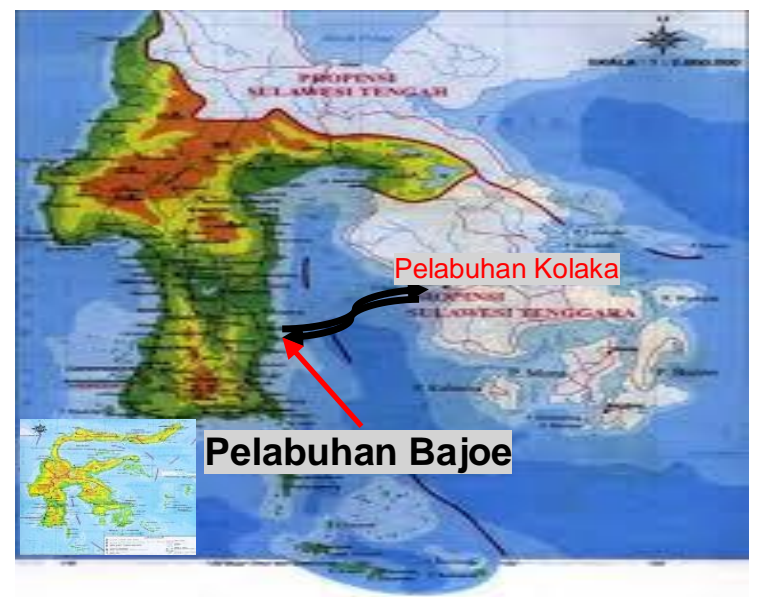

Gambar 1. Lokasi penelitian

Sistem transportasi yang diselenggarakan di Kabupaten Bone terdiri atas moda transportasi jalan raya, sungai, dan transportasi laut. Khusus untuk angkutan laut di Kabupaten Bone terdapat 8 pelabuhan. Salah satu diantaranya adalah pelabuhan penyeberangan Bajoe merupakan pelabuhan nasional. 2 pelabuhan regional, 4 pelabuhan lokal dan 1 pelabuhan rakyat. Angkutan laut merupakan salah satu sarana vital bagi perekonomian Kabupaten Bone. Pelabuhan Feri Bajoe merupakan pelabungan penyeberangan laut dengan menggunakan kapal jenis Ro-Ro yang melayani penumpang barang dan orang serta kendaraan bermotor seperti sepeda motor, truk barang, bus dan minibus dari beberapa Kabupaten/Kota di Sulawesi Selatan, Sulawesi Barat, Sulawesi Tengah menuju ke Kabupaten Kolaka Provinsi Sulawesi Tenggara serta kearah sebaliknya.

Berdasarkan data PT. ASDP Cabang Bajoe, Kota Makassar mendominasi $\pm 82 \%$ dari jumlah muatan yang ada. Kendaraan truk barang yang melalui pelabuhan fery Bajoe menyeberangkan barang-barang berupa kebutuhan pokok sehari-hari (beras, sayuran buah-buahan, dan hasil perternakan) serta hasil industri seperti garmen, bahan bangunan, mesin pertanian dan listrik untuk diseberangkan menuju pelabuhan fery Kolaka yang kemudian didistribusikan lewat darat ke daerah-daerah di Sulawesi Tenggara dan Sulawesi Tengah. Sebaliknya dari pelabuhan fery Kolaka ke pelabuhan fery Bajoe, kendaraan truk barang mengangkut barang berupa ikan, 
biji kakao, mente, kopra, kayu, madu, dan besi tua/bekas. $\pm 90 \%$ muatan truk menuju ke Makassar dan selebihnya $\pm 10 \%$ ke daerah-daerah lainnya di Sulawesi Selatan dan Sulawesi Barat. Jadwal pemberangkatan kapal fery perhari bervariasi sebanyak 3-4 trip yang disesuaikan dengan kondisi lapangan dan kondisi armada kapal fery yaitu pada pukul 14.00, 17.00, 20.00 dan 22.00 Wita yang dilayani secara bergiliran oleh 9 unit kapal fery. Adapun data muatan kapal fery dapat disajikan pada tebel 2 sebagai berikut :

Tabel 2. Jumlah muatan kapal fery di Pelabuhan Bajoe tahun 2007-2010.

\begin{tabular}{lrrrr}
\hline & \multicolumn{4}{c}{ TAHUN } \\
\cline { 2 - 5 } \multicolumn{1}{c}{ URAIAN } & 2007 & 2008 & 2009 & 2010 \\
\hline Jumlah Trip & 1.082 & 1.143 & 1.265 & 1.275 \\
Penumpang (Org) & 50.933 & 73.224 & 87.963 & 78.323 \\
Kendaraan (Unit) : & & & & \\
Sepeda Motor & 7.979 & 18.106 & 19.583 & 14.518 \\
Kend. Penumpang & 6.921 & 8.881 & 10.205 & 9.695 \\
Kend. Barang & 10.761 & 12.263 & 14.825 & 15.958 \\
\hline
\end{tabular}

Jumlah penumpang persatuan waktu berfluktuasi mengikuti musim liburan dan hari raya keagamaan. Sedangkan khusus untuk muatan kendaraan telah mencapai titik jenuh sehingga terjadi antrian panjang di terminal pelabuhan. Antrian kendaraan tersebut dapat mencapai 1 minggu. Hal ini menyebabkan membengkaknya biaya operasional pemilik kendaraan dan ketidaktepatan waktu pengiriman barang. Salah satu hal utama yang perlu mendapatkan perhatian guna meningkatkan keterpaduan dengan angkutan jalan termasuk mengatasi antrian kendaraan di pelabuhan yaitu menyangkut kapasitas total yang didalamnya termasuk jumlah kapal dan kapasitas muatan perkapal.

Tabel 3. Kapasitas muat kapal fery Bajoe-Kolaka

\begin{tabular}{|c|c|c|c|}
\hline Nama Kapal & GT & Penumpang & Kendaraan \\
\hline KMP. Merak & 692 & 365 & 17 \\
\hline KMP. Tuna & 831 & 342 & 20 \\
\hline KMP. Kota Bumi & 1.080 & 361 & 25 \\
\hline KMP. Mishima & 1.172 & 282 & 20 \\
\hline KMP. Muchlisa & 725 & 293 & 16 \\
\hline KMP. Windu Karsa & 1.376 & 395 & 30 \\
\hline KMP. Kota Muna & 725 & 330 & 25 \\
\hline KMP. Pelangi Nusantara & 909 & 325 & 20 \\
\hline KMP. Permata Nusantara & 1.504 & 256 & 25 \\
\hline Jumlah & 9.070 & 2.949 & 198 \\
\hline Rata - Rata & $1.001,6$ & 327 & 22 \\
\hline
\end{tabular}

Dari tabel 3, kapasitas rata-rata kapal fery sebesar 327 orang penumpang dan 22 unit kendaraan. Untuk penumpang orang, kapal fery memiliki kapasitas yang mencukupi kecuali pada saat-saat tertentu seperti hari libur dan hari besar keagamaan. Sedangkan khusus untuk muatan kendaraan dengan kapasitas yang ada saat ini tidak mampu melayani muatan yang ada efisien. Muatan kendaraan telah mencapai titik jenuh sehingga terjadi antrian panjang di terminal pelabuhan. Antrian kendaraan tersebut dapat mencapai 1 minggu. Hal ini menyebabkan membengkaknya biaya operasional pemilik kendaraan dan ketidaktepatan waktu pengiriman barang. Hal ini menuntut untuk segera diadakannya penambahan kapasitas kapal, baik dari segi jumlah kapal ataupun pengadaan kapal dengan kapasitas yang lebih besar. 
Berdasarkan data dari Dinas Pekerjaan Umum dan SDA Kabupaten Bone pada tahun 2009, Kabupaten Bone memiliki total jaringan jalan sepanjang 2.884,79 $\mathrm{km}$ dengan rincian jalan nasional sepanjang $207,25 \mathrm{~km}$, jalan provinsi $173,70 \mathrm{~km}$ dan panjang jalan kabupaten $2.503,84 \mathrm{~km}$.

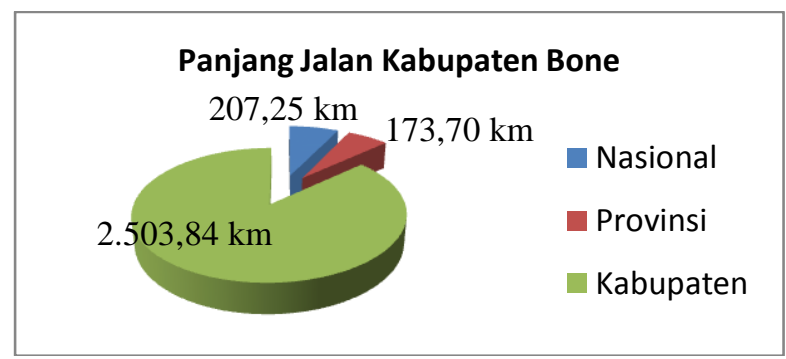

Gambar 2. Panjang status jalan di Kabupaten Bone

Pola jaringan jalan yang dikembangkan di Kota Watampone secara umum merupakan penggabungan pola grid dan linier sistem.

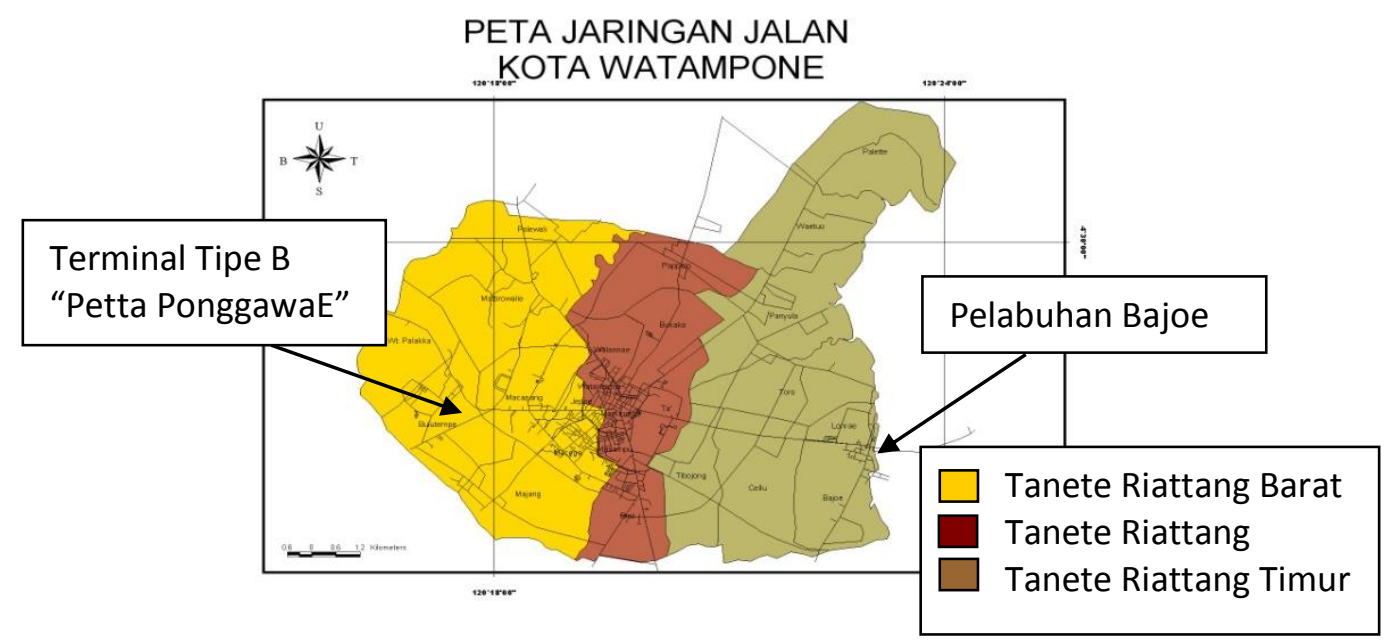

Gambar 3. Peta jaringan jalan di Kota Watampone

Titik simpul pelayanan transportasi jalan dikota Watampone dilayani oleh Terminal tipe B Petta PonggawaE dengan luas 10 Ha, terletak di Kecamatan Tanete Riattang Barat dan berjarak $\pm 15 \mathrm{~km}$ dari pelabuhan Bajoe. Berdasarkan data dari Dinas Perhubungan Kabupaten Bone, trayek dari Terminal Petta PunggawaE ke Bajoe dan Bajoe-Terminal Petta Ponggawae dilayani oleh angkutan umum Bus Kecil (pete-pete) sebanyak 100 unit, tapi khusus yang melayani akses ke pelabuhan Bajoe hanya sebanyak 30 unit. Selain itu akses dari dan ke pelabuhan Bajoe dilayani pula oleh angkutan kota dalam provinsi (AKDP) berjumlah 30 unit mini bus yang langsung melayani penumpang masuk dan keluar Kabupaten Bone diantaranya ke Makassar, Maros, Soppeng, Wajo, Sinjai, Bulukumba, Sidrap, Parepare dan pinrang serta Bus angkutan kota antar provinsi (AKAP) yang melayani rute Sulawesi Barat Sulawesi Tenggara dan Sulawesi Tengah - Sulawesi Tenggara.

Berdasarkan hasil pengambilan data Lalu Lintas Harian Rata-rata (LHR) pada ruas jalan Makassar-Watampone sebagai jalur dominan yang dilalui oleh muatan penumpang dan kendaraan dari dan ke Pelabuhan Bajoe didapatkan volume arus lalu lintas pada jam puncak adalah $421 \mathrm{smp} / \mathrm{jam}$ dan kapasitas jalan $2.509 \mathrm{smp} / \mathrm{jam}$, 
kemudian diolah berdasarkan Manual Kapasitas jalan Indonesia (MKJI) tahun 1997, didapatkan hasil perhitungan sebagai berikut:

Tabel 4. Arus total, kapasitas, dan derajat kejenuhan ruas jalan Makassar-Watampone

\begin{tabular}{cccc}
\hline $\begin{array}{c}\text { Arus Total } \\
\mathrm{Q}(\mathrm{smp} / \mathrm{jam})\end{array}$ & $\begin{array}{c}\text { Kapasitas } \\
\mathrm{C}(\mathrm{smp} / \mathrm{jam})\end{array}$ & $\begin{array}{c}\text { Derajat Kejenuhan } \\
(\mathrm{DS})\end{array}$ & Tingkat Pelayanan \\
\hline 421 & 2.509 & 0,17 & $\mathrm{~A}$ \\
\hline
\end{tabular}

Dari tabel dihasilkan derajat kejenuhan 0,17 atau tingkat pelayanan A yang berarti arus lalu lintas bebas antara satu kendaraan dengan kendaraan lainnya, besarnya kecepatan sepenuhnya ditentukan oleh keinginan pengemudi dan sesuai dengan batas kecepatan yang telah ditentukan. Tapi walaupun demikian yang perlu diperhatikan bahwa akses jalan Makassar-Watampone melewati tiga titik daerah pegunungan sehingga terdapat jalur yang berbelok-belok dan terjal serta di beberapa titik terdapat penyempitan badan jalan dan terjal karena diapit oleh tebing bebatuan sehingga tidak memungkinkan kendaraan truk barang berpapasan dengan normal (kendaraan dari salah satu arah harus berhenti) dan rawan terjadi kecelakaan. Hal ini memerlukan penanganan berupa peningkatan jalan dengan melakukan pelebaran jalan pada jalur existing atau jalur baru agar kendaraan besar dapat berpapasan dengan leluasa.

Pola pergerakan penumpang di pelabuhan Bajoe dapat dibagi 2 yaitu: (1) penumpang yang menggunakan Bus dari daerah asalnya dan selanjutnya menyeberang menggunakan kapal fery dengan tetap menggunakan/menumpang bus yang sama di atas kapal dan melanjutkan perjalanan sampai ke tujuan; (2) penumpang yang menggunakan trasportasi darat berupa mini bus, ojek, atau kendaraan pribadi sampai ke terminal pelabuhan, kemudian berpindah moda ke kapal fery penyeberangan dan begitu pula arah sebaliknya. Penumpang yang melakukan perpindahan moda ini dilayani oleh 30 unit mini bus yang langsung mengantar penumpang ke berbagai tujuan keluar kabupaten Bone dan 100 unit angkutan kota bus kecil (pete-pete) yang melayani rute pelabuhan Bajoe-Terminal Petta PunggawaE.

Angkutan kendaraan dan barang yang ada di pelabuhan menggunakan fasilitas terminal pelabuhan sebagai tempat antrian sebelum naik ke kapal fery. Terminal yang ada saat ini mampu menampung sekitar 150 kendaraan per satuan waktu. Kapasitas terminal tersebut dapat menampung angkutan kendaraan dan barang dari dan ke pelabuhan Bajoe yang $80 \%$ - 90\% didominasi oleh kendaraan dari dan ke Makassar harus menempuh rute perjalanan yang berbelok-belok dan terjal serta di beberapa titik terdapat penyempitan badan jalan karena diapit oleh tebing bebatuan dan jurang sehingga tidak memungkinkan kendaraan truk barang berpapasan dengan normal (kendaraan dari salah satu arah harus berhenti). Hal ini dapat mengurangi tingkat keselamatan dan harus menjadi fokus perhatian dalam menata jaringan konektifitas pelabuhan Bajoe yang menghubungkan dengan Kota Makassar dan Kabupaten Maros. Untuk mengatasi panjangnya antrian kendaraan di pelabuhan Bajoe selain mengadakan tambahan kapasitas/unit kapal fery, hal yang perlu dikaji sebagai alternatif adalah perbaikan jalan Trans Sulawesi yang menghubungkan Sulawesi Selatan dengan Sulawesi Tenggara dengan rute MakassarPalopo-Malili-Kolaka-Kendari sejauh $\pm 1.075 \mathrm{~km}$. Sehingga kendaraan truk barang yang tidak terlayani oleh pelabuhan Bajoe dapat memilih alternatif trans darat. 
Pembobotan kriteria sebagai tahap awal dari analisis dengan metode AHP dilakukan dengan cara menyebarkan kuisioner ke masing-masing instansi yang mempunyai tugas dan fungsi menangani pelabuhan Bajoe dan Angkutan Jalan. Petugas dari masing-masing instansi ini berfungsi sebagai stakeholder yang memberikan penilaian tentang tingkat kepentingan masing-masing kriteria yang digunakan dalam penelitian ini. Kriteria-kriteria yang digunakan: (1) angkutan Penyeberangan, terdiri dari kapasitas/jumlah kapal fery, waktu operasi, dan biaya transportasi; (2) transportasi penyeberangan, terdiri dari akses jalan ke pelabuhan (Makassar-Bone), angkutan khusus Makassar-Bajoe, dan trans darat Sulsel-Sultra.

Tingkat 1 :

Fokus

Tingkat 2 :

Kriteria

Tingkat 4 : Alternatif

Tingkat 3 :

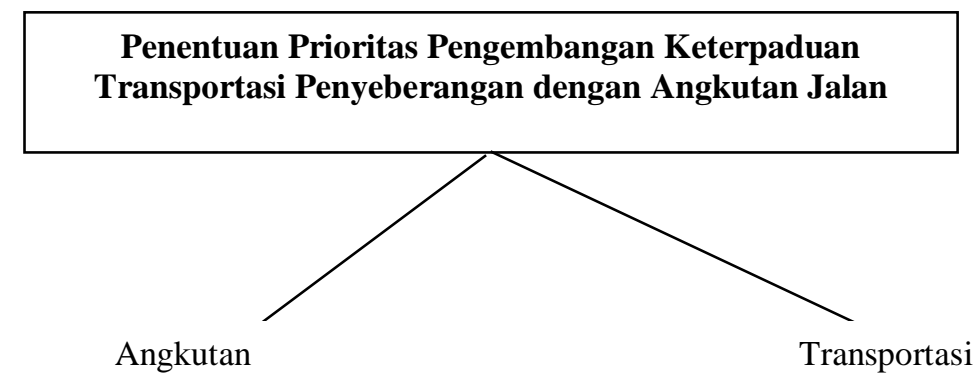

$$
\text { Penyeberangan }
$$

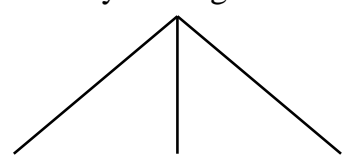

Kapasitas/ Waktu Operasi Biaya

Sub Kriteria Jumlah Fery Pelabuhan (Mks-

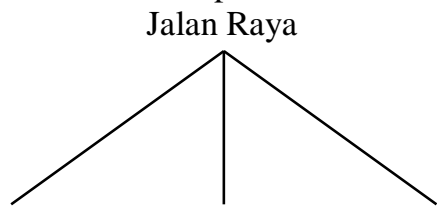

Akses Jalan Bajoe

Angkutan Khusus Mks-Bajoe

Trans Darat Sulsel-Sultra

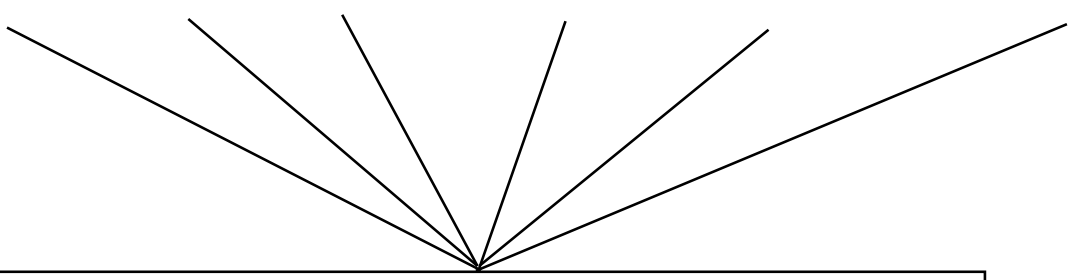

Keterpaduan Transportasi Penyeberangan dengan Angkutan Jalan

Gambar 4. Pohon hirarki tahapan pengembangan

Dari pembahasan permasalahan diperoleh alternatif pilihan untuk pengembangan keterpaduan transportasi penyeberangan dengan angkutan jalan adalah penambahan kapasitas/jumlah armada kapal fery, peningkatan/pelebaran akses jalan Makassar-Bone, penyediaan angkutan penumpang khusus MakassarBajoe dan perbaikan jalan trans Sulsel-Sultra. Selanjutnya penentuan prioritas pengembangan dengan proses Analisis Hirarki Proses (AHP) dilakukakan menggunakan bantuan software expert choice versi 11 dan didapatkan hasil sebagai berikut : 


\section{Synthesis with respect to: Goal: Keterpaduan Angkutan Penyeberangan dengan Angkutan Jalan}

$$
\text { Overall Inconsistency = .02 }
$$
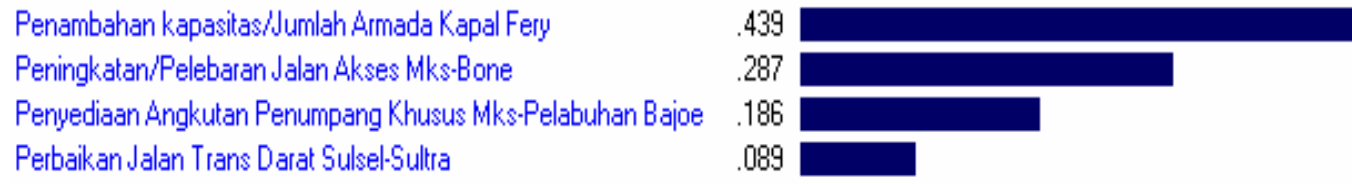

Gambar 5. Urutan prioritas pengembangan ketepaduantransportasi penyeberangan dengan angkutan jalan raya

Nilai inkonsistensi yang didapatkan adalah $0,02(<0,1)$ yang berarti pendapat yang diberikan oleh setiap responden konsisten. Maka didapatkan prioritas untuk pengembangan keterpaduan transportasi penyeberangan dengan angkutan jalan raya sebagai berikut: (1) penambahan kapasitas/jumlah armada kapal fery, peningkatan/pelebaran akses jalan Makassar-Bone, penyediaan angkutan penumpang khusus Makassar-Bajoe, perbaikan jalan trans Sulsel-Sultra.

\section{PENUTUP}

Armada kapal fery yang beroperasi di pelabuhan Bajoe sebanyak 9 buah dengan jadwal operasi sebanyak 3-4 trip perhari belum mampu melayani besarnya permintaan muatan khususnya muatan kendaraan truk barang. Hal ini terlihat dengan panjangnya antrian kendaraan di terminal pelabuhan. Sedangkan akses jalan Makassar-Bone yang merupakan jalur utama muatan di pelabuhan Bajoe memiliki tingkat pelayanan A dengan derajat kejenuhan 0,17.

Untuk mendukung pengembangan keterpaduan angkutan penyeberangan dengan angkutan jalan dibutuhkan penanganan permasalahan berturut-turut adalah penambahan kapasitas/jumlah armada kapal fery, peningkatan/pelebaran akses jalan Makassar-Bone, penyediaan angkutan penumpang khusus Makassar-Bajoe dan perbaikan jalan trans Sulsel-Sultra.

\section{DAFTAR PUSTAKA}

Adisasmita, R., 2006. Perencanaan Jaringan Transportasi. LEPHAS UNHAS, Makassar.

Badan Pusat Statistik Kabupaten Bone, 2009. Bone Dalam Angka.

Hadjisarosa, P., 1982. Konsepsi Dasar Pengembangan Wilayah di Indonesia. Departemen Pekerjaan Umum, Jakarta.

Hany, Ahmed Assqol., 2010. Simulasi Sistem Transportasi Kapal Ferry, Studi Kasus Pelabuhan Penyeberangan Ketapang-Gilimanuk, ITS, Surabaya.

Jinca, M,Y. dkk, 2002. Perencanaan Transportasi. Kerjasama Fakultas Teknik Unhas Makassar dengan Pusat Pendidikan Keahlian Teknik BPSDM Departemen Prasarana Wilayah, Bandung.

Jinca, M,Y., 2009. Keterpaduan Sistem Jaringan Antar Moda Transportasi di Pulau Sulawesi. Jurnal Transportasi, Makassar.

Miro, F., 2004. Perencanaan Transportasi. Erlangga, Jakarta.

Morlok, E. K., 1985. Pengantar Teknik Perencanaan Transportasi. Terjemahan oleh Hainin, J.K., Erlangga, Jakarta. 
Peraturan Menteri Perhubungan No. KM 49 Tahun 2005. Tentang Sistem Transportasi Nasional, Jakarta.

Pedoman Penulisan Tesis dan Disertasi Edisi 4, Program Pasca Sarjana Universitas Hasanuddin, Makassar.

Nasution, M.N., 2004. Manajemen Transportasi. Ghalia Indonesia, Jakarta.

Warpani, S., 1990. Merencanakan Sistem Perangkutan. ITB, Bandung. 
PENA TEKNIK: Jurnal Ilmiah Ilmu-Ilmu Teknik

Volume 1, Nomor 1, Maret $2016: 27$ - 38 